\title{
ACRL Legislative Policy and General Guide to Legislative Action
}

Prepared by the ACRL Legislation Committee; submitted to the ACRL Board of Directors for review January 5, 1982; unanimously endorsed by the Board January 26, 1982.

Committee members: Keith W. Russell, chair; Wendell A. Barbour; Deborah Brown (intern); Gloria Terwilliger Brown; Bob Carmack; John C. Heyeck; Vincent Jennings (intern); Robert $L$. Klassen; Nancy C. Kranich; James D. Lockwood; Charlene Mason; Elaine Sloan; Jesse Cottman Smith; Paul Vassallo; Faye Zipkowitz.

\section{INTRODUCTION}

This document presents a brief legislative policy statement for the Association of College and Research Libraries (ACRL) and the rationale behind that policy; describes, in a general way, the means by which that policy can be implemented; and serves as a general guide to legislative action by ACRL.

The policy set forth here is intended to support, complement, and in some instances augment the legislative policy of the American $\mathrm{Li}$ brary Association (ALA), ACRL's parent organization, while at the same time serving the interests of ACRL. Legislative actions of ACRL are closely intertwined with those of ALA, its divisions and units.

\section{ACRL Legislative Policy Statement}

The Association of College and Research Libraries (ACRL) will take appropriate action whenever necessary to recommend and/or promote legislation (including statutory and administrative laws, executive policies, standards, rulings, and legal decisions) and international agreements which enhance library services to the academic and research communities and which, in other ways, contribute to the welfare and development of academic and research libraries and support the mission and goals of ACRL. Appropriate action will also be taken to protest legislation and international agreements which adversely affect academic and research libraries and the mission and goals of ACRL.

\section{Rationale}

Actions of the federal government (and to a lesser extent foreign, state and local governments) greatly affect progress toward ACRL's mission and goals, and ACRL must be willing and prepared to influence government action. The federal government, via legislation, regulations, executive policies, programs, and legal interpretations, provides fiscal support and/or regulations which directly affect academic and research li- braries, their parent institutions, and related national institutions and activities. In addition to existing and planned legislation and regulation which may need to be supported, modified, or eliminated, new legislation and regulation may be the most effective way of addressing complex problems affecting academic and research libraries.

\section{Priorities and Timing of ACtion}

Each year the ACRL Legislation Committee will develop a Legislative Program for ACRL which reflects the current legislative scene and the interests of ACRL, and which takes into consideration the view of the ACRL Board of Directors and the ACRL Membership. This program will be a basic list of federal legislation goals and objectives to be pursued by the committee and the membership during the year. Progress on these goals and objectives shall serve as part of the annual report of the committee.

Naturally, allowance must be made each year for necessary changes in priorities and for action on pressing issues that arise.

\section{Possible Actions}

Implementation of the ACRL Legislative Policy, and programs which support that policy, will require that ACRL take actions such as the following:

- Review and analyze implications of legislation (including statutory and administrative laws, rulings, or legal decisions) and international agreements which do or could affect academic and research libraries.

- Communicate the results of such reviews and analyses, and the ACRL viewpoint resulting from those reviews and analyses to public officials, other associations, etc.

- Mobilize support, both within and outside ACRL, for legislation, and agreements beneficial to academic and research libraries; mobilize support for adequate funding of existing library programs; mobilize opposition to legislation and agreements which adversely affect academic and research libraries.

- Influence public officials by such means as: educating them about the importance of library and information issues, and the consequences of legislation and regulations for libraries, higher education, and the national information system.

- Educate ACRL members and friends of academic and research libraries about the political process and the issues related to libraries, and how they can effectively exercise their citizen 
privileges and responsibilities to influence political opinion.

- Encourage and motivate members to be involved in the political process, provide them as many resources as possible to facilitate their involvement, keep them informed of legislative developments, and prompt them when political action is needed.

- Act cooperatively with other divisions and units of ALA, ALA itself, other library and information associations, professional and educational organizations, the publishing and communication industries, and others, when appropriate, to support or block legislation and regulations serving mutual interests and needs.

\section{Organization for ACtion}

The following committees, boards, offices, etc., all have roles to play in the implementation of ACRL legislative activities, and in one way or another influence ACRL legislative actions. The charges to some of these groups, and some of their key functions relative to the ACRL Legislation Committee are:

\section{A. ACRL Legislation Committee (13 members)}

- Charge: "To take a direct and active role in formulating objectives and in planning legislative action at the national level which may affect the welfare of academic and research libraries; to take responsibility for initiating as well as promoting such programs; to work through normal ALA channels and other channels for their passage and implementation."

\section{B. ACRL Office}

- Provides support services for regular work of the committee and for legislative actions.

- Monitors legislative developments and initiates action via the committee and/or directly, as needed; assists the committee in setting legislative priorities for ACRL.

- Keeps ACRL members (and others) aware of legislative issues and activities, and broader issues related to legislation, through publications of the association (CむRL News, College and Research Libraries) and other means.

\section{ACRL Board of Directors (14 members)}

- Approves resolutions and other legislative activities of ACRL and the ACRL Legislation Committee, and the funding needed for such activities; assists the committee in setting legislative priorities for ACRL, and in carrying out legislative programs.

\section{ACRL Legislative Network}

- Consists of approximately 220 academic librarians, nationwide, who have volunteered to write legislators and in other ways take action on legislative issues affecting academic and research libraries. Action of this network is coordinated by the ACRL Legislation Committee with assistance from the ALA Washington Office. Contact with the network is maintained via memoranda and urgent memoranda (i.e., "calls for action") sent to the network as needed.

\section{E. ACRL Membership}

- Assists the committee in setting legislative priorities for ACRL, and carries out much of the prescribed action either individually or through the ACRL committees, sections, discussion groups, chapters, and the ACRL Legislative Network.

\section{F. ALA Washington Office}

- Keeps ACRL members (and members of ALA, and other interested persons) aware of legislative developments via direct contact, formal presentations, the ALA Washington Newsletter, etc.

- Provides assistance to the ACRL Legislation Committee, as needed and available, in the preparation and mailing of urgent memoranda to the ACRL Legislative Network, provides advice and recommendations to the committee, and prompts the committee when action would be useful.

- Serves as a liaison to other associations seeking to influence legislation related to libraries, information, and higher education.

\section{G. ALA Legislation Committee (10 members)}

- Charge: “To have full responsibility for the Association's total legislative program on all levels-federal, state, and local. To recommend legislative policy and programs for Council ap-

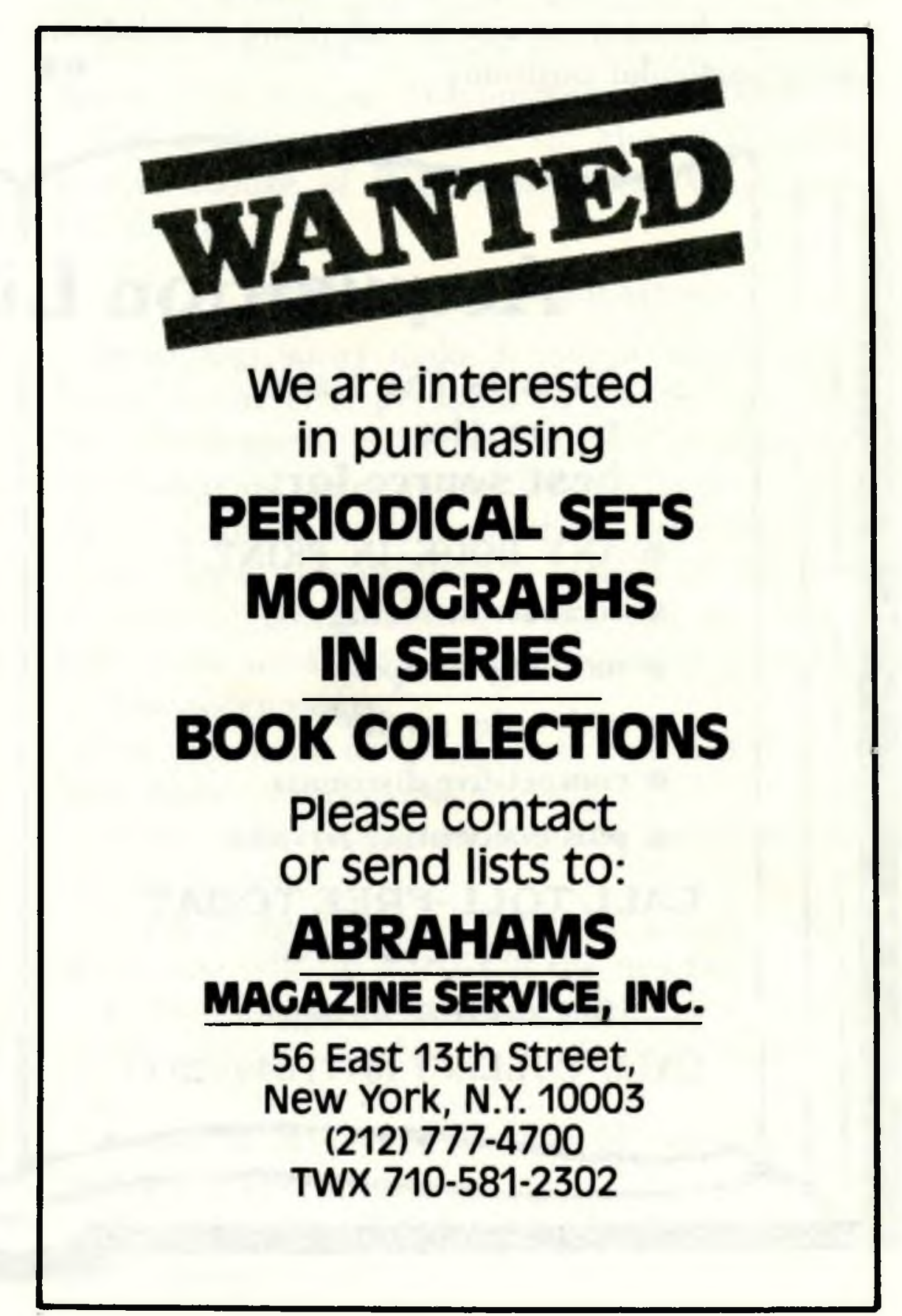


proval and to take the necessary steps for implementation. To protest any legislation or executive policy adversely affecting libraries. To seek rulings and interpretations of laws and regulations affecting the welfare and development of libraries. To represent the ALA before executive and legislative branches of government as required at all levels. To provide a forum within ALA to gather information about needed legislation and to keep all units of the Association informed of the ALA legislative programs. To direct the activities of all units of the Association in matters relating to legislation."

- Issues and regularly updates two publications: ALA Federal Legislative Policy, ALA Legislative Program.

- Sponsors the "Legislative Update" program presented at each annual and midwinter meeting of ALA.

\section{H. ALA Legislation Assembly (10 members)}

- Charge: "To act in an advisory and resource capacity to the ALA Legislation Committee. The individual members, named by the divisional boards to the assembly, shall serve as liaison to their divisional boards in matters relative to legislation." (Note: the chair of the ACRL Legislation Committee is the ACRL representative on the Assembly.)

\section{ALA Council}

- Acts on recommendations of the ALA Legislation Committee; puts the full weight of the Association behind issues by adopting resolutions taking particular positions.

\section{Serial Titles Still Vary}

To continue the work by the recently ceased publication Title Varies, the ALA Resources and Technical Services Division's Serials Section has established an Ad Hoc Committee to award the Worst Serial Title Change of the Year. Categories to be considered (in keeping with the Title Varies tradition) include:

1) Frivolous title changes for no apparent reason which produce no advantage.

2) The change of an old respected title unnecessarily.

3) Repeated title changes, the latest of which is no better than any of the former ones.

4) The "Et tu, Brute?" category for library publications that should know better (more recently known as the Snake in the Grass Award).

Nominations will be welcomed through June 1, 1982. Please supply a complete citation describing the change, including the number and/or date and title of the last issue with the old title; number and/or date of the first issue with the new title; and publisher's full name and address. Photocopies of relevant title pages are encouraged as verification.

Send nominations to: Miriam Palm, Serials Department, Green Library, Stanford University, Stanford, CA 94305.

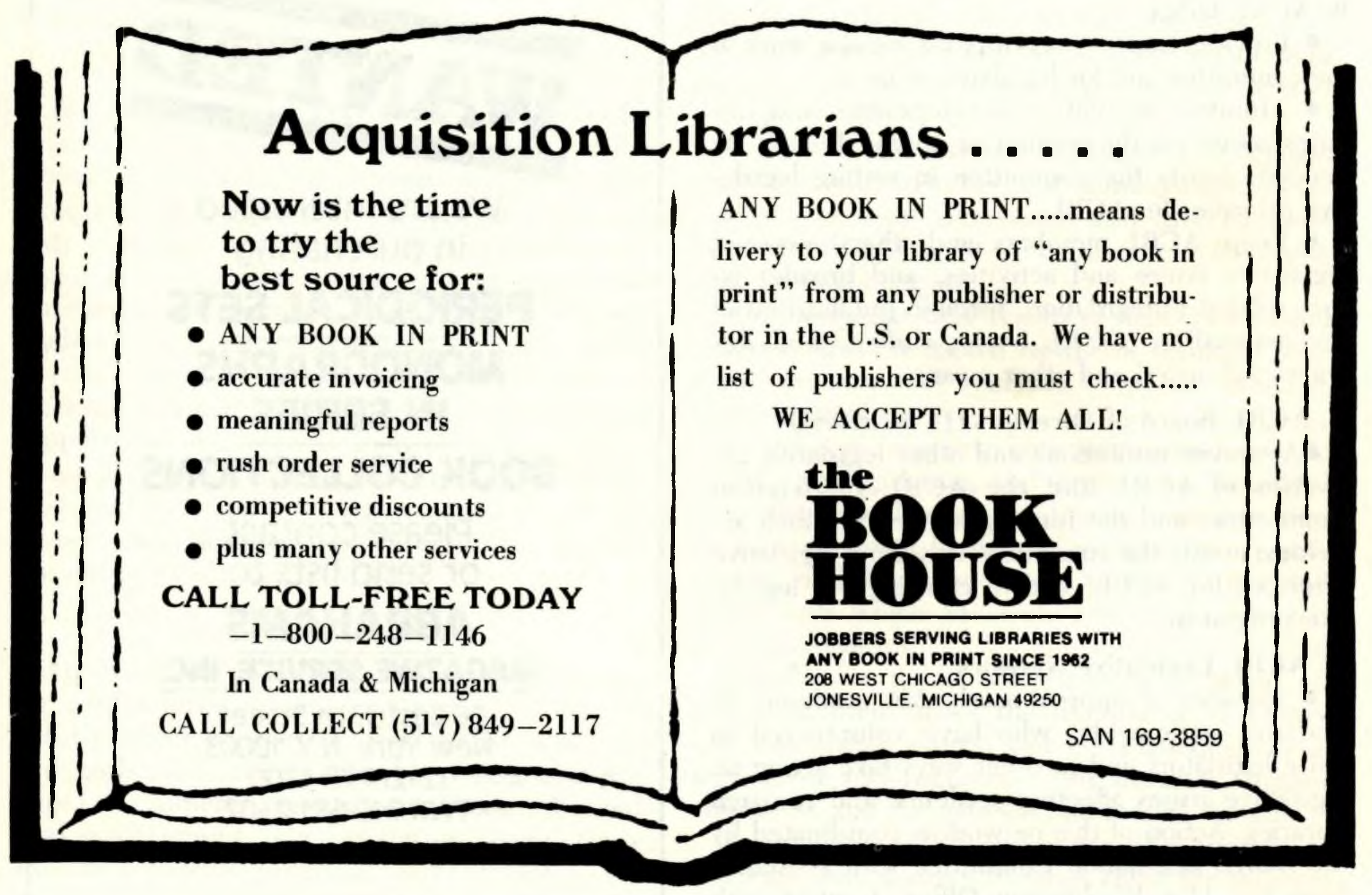

